\title{
Response of Onion( Allium Cepa L, ) to Different Irrigation Levels Under Drip and Convetional Furrow Irrigation With and Without Mulch at Melkassa, Central Rift Valley of Ethiopia
}

\author{
Gebeyehu Ashemi (Msc) \\ Water Resource Engineering and management \\ Ethiopian Institute of Agricultural Research (EIAR) \\ Melkassa Agricultural Research Center, P. O. Box: 436, Adama, Ethiopia
}

\begin{abstract}
Water is a scarce resource in Central Rift Valley of Ethiopia and is a major limiting factor for crop production. Onion is one of the major economically important vegetable crops grown under irrigation in central rift valley. The field experiment was conducted at Melkasa agricultural research center during the dry season to identify irrigation method and irrigation application level with and without mulch that maximizes productivity of onion per unit of water consumed and enhanced onion crop production. The experiment was carried out using split plot design inRCBD having twelve treatments with three replications. The FAO's recommended allowable Manageable depletion level of onion is $100 \%$. In this study $75 \%, 100 \%$ recommended and $125 \%$ were tested. The experiment consisted of two irrigation methods viz.,furrow irrigation and drip irrigation as main plot and three levels of Manageable allowable depletion viz., 125\%, 100\% and 75\% with and without mulch as subplot.The analysis of variance revealed that irrigation methods and management allowed depletion levels had a significant and $\mathrm{p}<0.05$ ) effect on onion vegetative parameters like plant height, leaf height and yield parameters like bulb diameter, bulb height, total bulb yield, marketable bulb yield, and water productivity. The highest and lowest onion vegetative and yield parameters were obtained from drip irrigation and furrow irrigation method, respectively. Moreover, the highest and lowest onion vegetative and yield parameters were obtained from drip irrigation under $75 \% \mathrm{MAD}$ with mulch and furrow irrigation under $125 \% \mathrm{MAD}$ without mulch, respectively. Further, their interaction had a significant effect on total bulb yield and water productivity. The maximum total bulb yield (37.1 ton/ha), marketable bulb yield $(33.1 \mathrm{ton} / \mathrm{ha})$, bulb diameter $(5.6 \mathrm{~cm})$, crop water use efficiency $\left(0.78 \mathrm{~kg} / \mathrm{m}^{3}\right)$ and irrigation water use efficiency, $\left(0.60 \mathrm{~kg} / \mathrm{m}^{3}\right)$ were observed from drip irrigation method at $75 \%$ MAD with mulch application, while significantly lower as $(30.5 \mathrm{ton} / \mathrm{ha}),(26.7 \mathrm{ton} / \mathrm{ha}),(5.0 \mathrm{~cm}),\left(0.53 \mathrm{~kg} / \mathrm{m}^{3}\right) \mathrm{and}$ $\left(0.40 \mathrm{~kg} / \mathrm{m}^{3}\right)$ respectively were recorded from furrow irrigation method at $125 \%$ MAD with out mulch application. Generally, drip irrigation was working efficiently according to its design and economically acceptable. Among all tested treatments drip irrigation method under 75\% MAD with mulch was the best practice because of its high yield and water productivity .
\end{abstract}

Keywords: Drip irrigation, Furrow irrigation, MAD, Onion, Water Use Efficiency

DOI: $10.7176 / \mathrm{JNSR} / 12-15-02$

Publication date:August $31^{\text {st }} 2021$

\section{Introduction}

Water is man kind's most vital and versatile natural resource. It is also considered as an essential resource for irrigation. Irrigation can be defined as an artificial application of water to soil for the purpose of supplying the moisture essential in the plant root-zone to prevent stress that may cause reduced yield and/or poor quality of harvest of crops (Reddy, 2010).

Irrigated agriculture is the largest water-consuming sector and it faces competing demands from other sectors, such as the industrial and the domestic sectors. The sector is also facing increasing challenges in the face of rapid population growth, decreasing availability of land and competition for scarce water resources. With an increasing population and less water available for agricultural production, the food security for future generations is at stake. Hence the key challenge for future is growing more food with less water by way of increasing crop water productivity (CWP). A higher CWP results in either the same production from fewer water resources, or a higher production from the same water resources, so this is of direct benefit for other water users (Kijne et al., 2003).

The competition for existing freshwater supplies will require a paradigmatic shift from maximizing productivity per unit of land area to maximizing productivity per unit of water consumed. This shift will, in turn, demand broad systems approaches that physically and biologically optimize irrigation water relative to water delivery and application schemes, rainfall, critical growth stages, soil fertility, location, and weather (Evans and Sadler, 2008).

Irrigation development is increasingly implemented in Ethiopia more than ever. Expansion of irrigated area combined with the efficient management of water will enhance the attainment of food security and poverty 
alleviation goals of the country. Although the country is well known for its vast water resources potential its erratic distribution both in space and time coupled with limited capacity is the most challenging problem that limited the contribution of the resources to the socio-economic development of the country (Mekonen, 2011).

Agricultural production particularly vegetable crops are intensively cultivated under irrigation in Central Rift valley (CRV) Ethiopia. The region is a semi-arid with limited water resources. Considering increasing demand for water combined with high evapotranspiration rates in the region, effective and efficient use of existing water resources need to be discovered.

Onion is one of the most important vegetable crops widely grown and economically important vegetable crops throughout the world (Brewster, 1997). It is also widely cultivated as source of income by many farmers in many places of Ethiopia. The country has a great potential to produce the crop throughout the year both for local consumption and export. The majority of onion production is found in the CRV of Ethiopia. The climate and soil condition of the region favors the production of the crop.

Traditionally, farmers in the central rift valley of Ethiopia have been using the most conventional surface irrigation system, most commonly the furrow irrigation system, for growing the crops. Furrow irrigation is characterized by low irrigation efficiency. Under common furrow irrigation, over irrigation is inevitable, particularly in the upper part of a field near the water source. Over-irrigation leads to greater water losses and leaches the pesticides and chemicals into the groundwater causing lower water application efficiency and pollution problems as well. The crop productivity under furrow irrigation can be achieved by applying the required amount at the right time. The crop is shallow rooted and sensitive to water stress. As a result it is commonly given light and frequent irrigation to avoid water stress (Doorenbos and Kassam, 1996). Maximum yield could be achieved with the achievement of the entire crop water requirement.

Drip irrigation is one of the most efficient forms of irrigation technology currently available. It is a technology by which water can be conserved and yield increase for farmers, especially those who are cultivating in semi-arid conditions of the world or in areas where competition over water resources is escalating. Drip irrigation offers many advantage over furrow irrigation including water saving, reducing labor required for irrigation, reducing soil erosion and increasing crop productivity. Therefore, the efforts are now warranted to harness the available quantities of water and put them to efficient use to realize higher productivity per drop (Solaimalai et al., 2005).

On-farm water use efficiency and hence water productivity can be improved by moving to a more efficient irrigation system. Sprinkler and drip irrigation can save non-effective water loss (Ali and Talukder, 2008). Modernization and optimization of irrigation systems can contribute to increasing water productivity (Playán and Mateos, 2006).

Management allowed depletion (MAD), sometimes called the readily available water (RAM) is the fraction of the total available soil water which is most easily extracted by the plant roots without creating stress. The water content approaching permanent wilting point (PWP) cannot be easily extracted by the plant roots. As ET occurs, the soil water reservoir begins to be depleted. As the soil dries, the remaining water is held more tightly by capillary forces in the soil, making it more difficult for the plant to extract it. For this reason, ET will start to decrease long before the PWP is reached. Since the lowest ET will generally reduce yields, growers should irrigate before the root zone water content reaches the level that restricts ET (Palanisami, 2002).

Hence, this study was initiated to identify appropriate irrigation method and optimal irrigation application level with and without mulch that will improve yield and water productivity of onion at Awash Melkassa.

\section{Materials and Methods}

\subsection{Description of the Study Area}

\subsubsection{Location}

The study was conducted at Melkassa Agricultural Research Center experimental site during 2017/18 dry season. The area is Located in the Central Rift Valley of Ethiopia. It is geographically located between latitude of $8024^{\prime}$ to $8026^{\prime} \mathrm{N}$, longitude of $39019^{\prime}$ to $39019^{\prime} \mathrm{E}$ and the mean altitude of the area is 1550 m.a.s.l (Figure 1). It is located about $107 \mathrm{~km}$ to the East of Addis Ababa, capital city of Ethiopia and 17 $\mathrm{km}$ Southeast of Adama. Loam and clay loam soil textures are the dominant soils of the area, which is classified as Lithosols with $\mathrm{pH}$ of 7. 

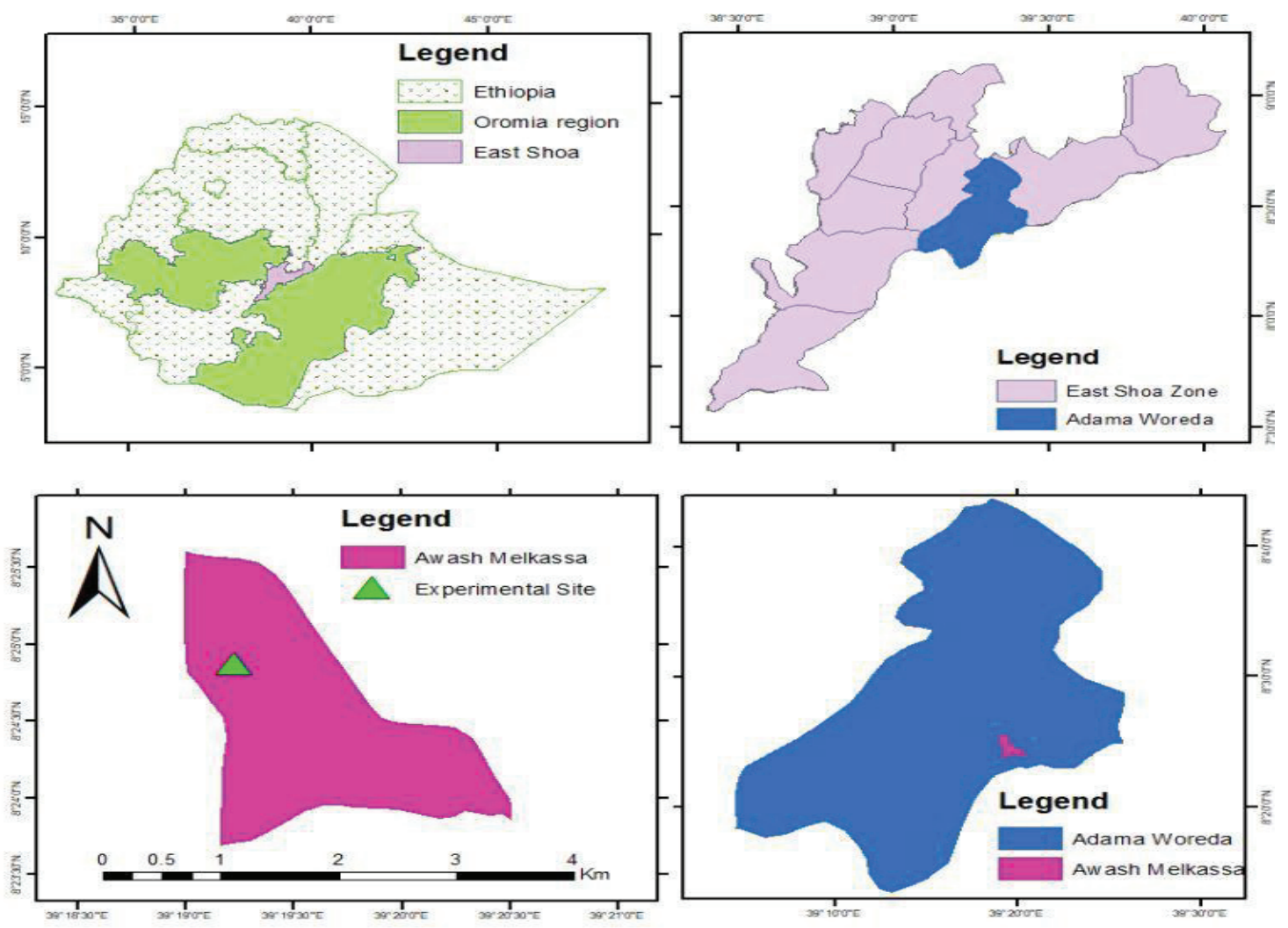

\subsubsection{Climate}

Figure 1. Location of the study area

Long-term $(1977$ - 2017) climatic record from station, average annual rainfall in the area is $824.9 \mathrm{~mm}$. The climate of the area is characterized as semi-arid with uni-modal low and erratic rainfall pattern. Kiremt season have got more rainfall about $67.4 \%$ of the total rainfall of the area occurs from June to September, with peak month of July and August. The mean maximum and minimum monthly rainfall is 204.2 and $9.6 \mathrm{~mm}$ occurs in the month of August and November, respectively. The mean maximum temperature varies from 26.3 to $31.0^{\circ} \mathrm{C}$ while the mean minimum temperature varies from 10.4 to $16.4^{\circ} \mathrm{C}$, with the average of $21.3^{\circ} \mathrm{C}$ (Figure 2 ).

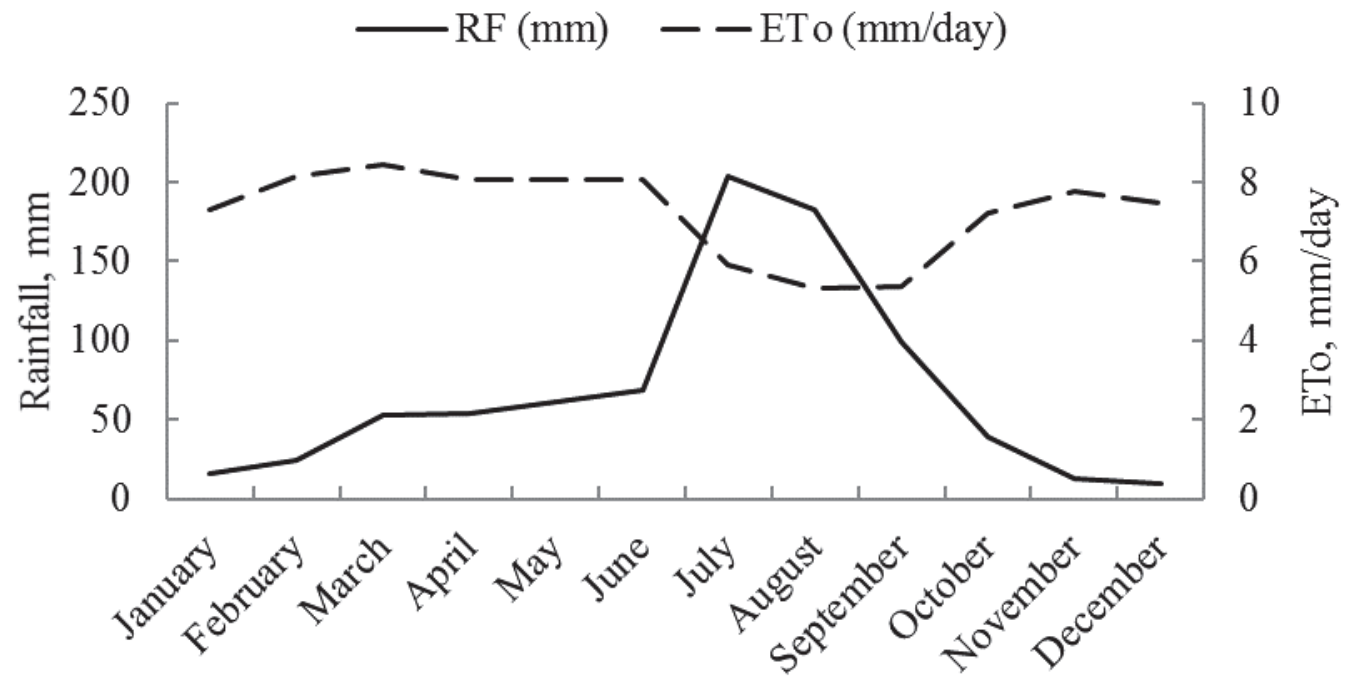

Month

Figure 2. Long-term monthly climatic water balance of the study area 


\subsection{Experimental procedures}

\subsubsection{Experimental design and treatments}

Treatments include two methods of irrigation: furrow irrigation (FI) and drip irrigation (DI), two levels of soil water depletion, 25\% below and above FAO's recommended allowable Manageable depilation level of onion ( $75 \%$ of and $125 \%$ of ASMDL) and a control irrigation application, FAO's recommended allowable Manageable depilation level of onion (100\%ASMDL*) and two mulching techniques : no mulch [NM], and white plastic mulch [PM] having twelve treatment combinations arranged in a split plot design in RCBD with three replications, in which the irrigation methods were used as main plot and the three irrigation applications together with the two mulching technique were used as sub-plot. The treatment combination is given in Tables 1 and 2 .

\begin{tabular}{|c|c|c|}
\hline \multirow{2}{*}{$\begin{array}{c}\text { Sub-plot } \\
\text { Irrigation Level }\end{array}$} & \multicolumn{2}{|c|}{ Main-plot - Irrigation method } \\
\hline & Drip Irrigation & Furrow Irrigation \\
\hline $75 \% M A D P M$ & $T 1$ & $T 7$ \\
\hline $75 \%$ MADNM & $T 2$ & $T 8$ \\
\hline $100 \%$ MADPM & $T 3$ & $T 9$ \\
\hline $100 \%$ MADNM & $T 4$ & $T 10$ \\
\hline $125 \%$ MADPM & $T 5$ & $T 11$ \\
\hline $125 \%$ MADNM & T6 & $T 12$ \\
\hline
\end{tabular}

Table 1. The exprimental treatments combinations

\begin{tabular}{ll}
\hline Treatment & \multicolumn{1}{c}{ Description } \\
\hline T1 & Drip irrigation method with $75 \%$ of MAD level with plastic mulch \\
T2 & Drip irrigation method with $75 \%$ of MAD level without plastic mulch \\
T3 & Drip irrigation method with $100 \%$ of MAD level with plastic mulch \\
T4 & Drip irrigation method with $100 \%$ of MAD level without plastic mulch \\
T5 & Drip irrigation method with $125 \%$ of MAD level with plastic mulch \\
T6 & Drip irrigation method with $125 \%$ of MAD level without plastic mulch \\
T7 & Furrow irrigation method with $75 \%$ of MAD level with plastic mulch \\
T8 & Furrow irrigation method with $75 \%$ of MAD level without plastic mulch \\
T9 & Furrow irrigation method with $100 \%$ of MAD level with plastic mulch \\
T10 & Furrow irrigation method with $100 \%$ of MAD level without plastic mulch \\
T11 & Furrow irrigation method with $125 \%$ of MAD level with plastic mulch \\
T12 & Furrow irrigation method with $125 \%$ of MAD level without plastic mulch
\end{tabular}

Table 2. Treatment description

\subsubsection{Preparation of the Experimental area}

Field experiment was carried out during dry cropping season (October - February) 2017/18 and the field was ploughed using tractor, leveled and made ready for plot layout. The experimental field plot layout was made by dividing the field in to 36 plots and each experiment plot has plot sizes of $3 \mathrm{~m}$ by $4 \mathrm{~m}$ to accommodate five furrows with spacing of $60 \mathrm{~cm}$ between ridges and $4 \mathrm{~m}$ furrow length. The plots and replications plot had a buffer zone of $2 \mathrm{~m}$ and $3 \mathrm{~m}$ between plots on none supplying and supplying canal sides, respectively to eliminate influence of lateral sub-surface water movement.

\subsubsection{Installation of drip irrigation sets}

In case of drip irrigation, the plots were leveled manually to create uniform plots within the given treatment. There were 18 plots laid out $4 \mathrm{~m}$ length, five laterals per plot, $60 \mathrm{~cm}$ spacing between laterals and $20 \mathrm{~cm}$ interval between emitters. Wooden platform to carry the water container was constructed. The height of the plat form was $1.5 \mathrm{~m}$ above the ground. The water container was drilled and 1 inch socket welded $10 \mathrm{~cm}$ above the bottom to provide the water pressure required to operate the system. The container on the platform was mounted in such a way that the water out let was at a height of $1.1 \mathrm{~m}$. A 1 inch male elbow, on the container water out let, was attached to female elbow, and flow regulator fittings were mounted at main line of each Tee connector. The water distribution system components $(32 \mathrm{~mm}$, main line) were laid and connected the water container to the $(25 \mathrm{~mm}, \mathrm{~s} \mathrm{u} \mathrm{b}$ main line) and sub main line connected to individual drip lines. The drip lines (laterals) of $16 \mathrm{~mm}$ diameter were unrolled and laid along the crop rows and each lateral served one row of crop. Emitter was inserted in the punched hole. The end of the laterals and the main lines were closed with end cup to avoid direct soil contact and thus prevent clogging.

\subsection{Crop Management Practices}

The experimental plots were pre-irrigated before three days to planting. Onion variety Nafis was planted on well prepared experimental field plots in third week of October 2017. This varitey was selected because of 
it's widely acceptance by local farmers and for its higher yield performance and disease resistance. The recommended rate of $200 \mathrm{~kg} / \mathrm{ha}$ DAP and $200 \mathrm{~kg} / \mathrm{ha}$ urea was uniformly applied to the plots. DAP was applied at planting time only whilst urea was applied in split application, half at planting and another half twenty days after planting.

Light irrigations was applied prior to start of treatments applications for ten days. The treatments applications was started on 28 October, 2017. Water applications for control irrigation treatments (ASMDL*) were based on the predetermined amount of irrigation water allowable soil moisture depletion for Onion $(\mathrm{p}=0.25)$ and those two levels of soil water depletion treatments $(75 \%$ of ASMDL, and $125 \%$ of ASMDL) were imposed as planned.

In furrow irrigation, each plot was irrigated using Parshall flume. In drip irrigation, each plot was irrigated through drip lines (laterals) of $16 \mathrm{~mm}$ diameter that was laid along the full length of each furrow bed. Depending on soil type, emitter was placed at $20 \mathrm{~cm}$ interval along the lateral lines. Water tanker of 2000 liters capacity was placed at $1.5 \mathrm{~m}$ above ground to supply the required irrigation water to a block of experimental field through main line that was connected with sub-main line and manifold of drip irrigation system. All cultural practices were done in accordance to the recommendation made for the area.

\subsection{Irrigation Water Source and Management}

\subsubsection{Irrigation water source and quality}

The source of water for this experiment was used from Awash River. Water quality analysis prior to installation and use of drip irrigation has been made. The electrical conductivity of (EC ) of the irrigation water was $1.12 \mathrm{dS} / \mathrm{m}$, which is between $700 \mu \mathrm{mhos} / \mathrm{cm}$ and $3000 \mu \mathrm{mhos} / \mathrm{cm}$. Thus there is moderate limitation to use this water for irrigation.

\subsubsection{Irrigation management}

The amount of water that can be extracted by plant roots is held in the soil in an 'available' form. The actual volume of water that can be obtained from the soil profile depends on the depth of the root system. Not all of the water found in the root zone was actually be taken up by roots. The total available water (TAW), stored in a unit volume of soil, is approximated by taking the difference between the water content at field capacity (FC) and at permanent wilting point (PWP). The TAW is expresses as:

$$
\left.\mathrm{TAW}=(\mathrm{FC}-\mathrm{PWP})^{*} \mathrm{BD} * \mathrm{Dz}\right) / 100
$$

where; $\mathrm{FC}$ and PWP in $\%$ on weight basis, BD is the bulk density of the soil in $\mathrm{gm}^{-3}$, and $\mathrm{Dz}$ is the maximum effective root zone depth in $\mathrm{mm}$. The bulk density, $\mathrm{BD}$, is the mass of a soil in a unit volume for undisturbed soil condition and is expressed on dry weight basis of the soil as:

$\mathrm{BD}=\mathrm{Ms} / \mathrm{Vt}$

where Ms is the weight of oven dry soil (gm), and Vs is the volume of the same soil $\left(\mathrm{cm}^{3}\right)$.

For maximum crop production, the irrigation schedule will be fixed based on readily available soil water (RAW). The RAW is the amount of water that crops can extract from the root zone without experiencing any water stress. The RAW was computed from the expression:

$$
\text { RAW }=\text { p*TAW }
$$

where; RAW in mm, $\mathrm{p}$ is in fraction for allowable/permissible soil moisture depletion for no stress and TAW is total available water in mm.

Soil moisture will be monitored gravimetrically at $15 \mathrm{~cm}$ and soil depth increments up to $60 \mathrm{~cm}$ soil depth ( 15 $30,30-45$ and $45-60 \mathrm{~cm}$ ) with neutron probe in a single replication. Permissible soil moisture depletion will be taken as ASMDL* requirement and all other treatments will be adjusted accordingly to irrigate the plots. The depth of irrigation supplied at any time will be obtained from a simplified water balance equation which is expressed as:

$$
\mathrm{In}=\mathrm{ETc}-\mathrm{Pe}
$$

where In is the net irrigation depth $(\mathrm{mm})$, ETc is the crop water requirement $(\mathrm{mm})$ and Pe is the effective rainfall $(\mathrm{mm})$ which is a part of rainfall that enters in to the soil and makes available for crop production. The effective rainfall we estimated using dependable rain (FAO/AGLW formula) method as given by (Allen et al., 1998) as.

$$
\begin{aligned}
& \mathrm{Pe}=0.6 * \mathrm{P}-10 \text { for month } \leq 70 \mathrm{~mm} \\
& \mathrm{Pe}=0.8 * \mathrm{P}-24 \text { for month } \geq 70 \mathrm{~mm}
\end{aligned}
$$

where $\mathrm{Pe}$ is the effective rainfall $(\mathrm{mm})$ and $\mathrm{P}$ is total rainfall $(\mathrm{mm})$.

The gross irrigation requirement will be obtained from the expression:

$$
\begin{aligned}
& \operatorname{Ig}=\frac{\mathrm{In}}{\mathrm{Ea}} \quad \text { Furrow irrigation } \\
& \mathrm{Ig}=\frac{\mathrm{In} \text { x w.a }}{\mathrm{Eg}} \text { Drip irrigation }
\end{aligned}
$$


where; Ig is the gross irrigation depth (mm); Ea is the field application efficiency (\%) and w.a. is the wetted area $(\%)$.

In the case of furrow irrigation, knowing the application efficiency of the furrows $(60 \%)$, the time required to deliver the desired depth of water into each furrow will be calculated using the equation:

$$
\mathrm{T}=(\mathrm{dxWxL}) /(6 \mathrm{xQ})
$$

where; $\mathrm{d}=$ gross depth of water applied $(\mathrm{cm}), \mathrm{W}$ and $\mathrm{L}=$ width and length $(\mathrm{m})$ of the experimental plot, $\mathrm{T}=$ application time ( $\mathrm{min})$ and $\mathrm{Q}$ is flow rate (discharge) (1/s). Soil moisture depletion at any soil moisture level will be observed with the following expression as:

$$
\mathrm{SMD}=(\mathrm{FC}-\mathrm{MC}) \mathrm{xDzr}
$$

where, $\mathrm{SMD}=$ soil moisture depletion $(\mathrm{mm}), \mathrm{FC}=$ volumetric soil moisture content at field capacity $(\mathrm{mm}), \mathrm{MC}=$ volumetric moisture content at time of irrigation $(\mathrm{mm})$, and Dzr $=$ Depth of effective root zone $(\mathrm{mm})$.

In the case of drip irrigation, knowing drip/emitter size, length of lateral and the number of laterals per plot, the time required to deliver the desired depth of water will be calculated as follows:

Number of Emitters per lateral $=\quad$ Lateral length $(\mathrm{m})$

Emitter spacing $(\mathrm{m})$

Flow rate required per plot $=$ number of emitters per lateral $\mathrm{x}$ number of laterals per plot $\mathrm{x}$ emitter discharge (lt/sec)

Time required to irrigate a plot $(\mathrm{sec})=$ gross irrigation $(\mathrm{ltr}) /$ Flow rate required per plot $(1 \mathrm{t} / \mathrm{sec})$.

\subsection{Data Collection}

\subsubsection{Climatic data}

Data on daily climate of the site was collected from the Melkassa Agro-meteorological observatory. The reference evapotranspiration (ETo) was computed using Penman-Monteith method, CROPWAT ver. 8.0 window based computer model from the climatic data gathered from Melkasa Agricultural Research Center. The Onion crop evapotranspiration (ETc) for each day was computed by multiplying the ETo by the crop coefficient (Kc) values obtained from FAO (1977) for each of the four stages of Onion, initial, development, mid and late season. The Kc values represented the ratio of crop evapotranspiration (ETc) and reference evaporation (ETo) rate each day. The effective rainfall was computed by the CROPWAT program from the monthly total rainfalls. The net daily crop water requirement was computed by reducing the ETc by the daily effective rainfall. The gross water requirement was computed by applying field application efficiency.

\subsubsection{Crop Data}

Data on plant height, leaf height and leaf number per plant was recorded from five randomly selected plants in three middle rows of each experimental plot and the same plant was used for subsequent measurement. Data on total yield and yield components such as the Total bulb yield, Marketable bulb yield, bulb diameter, bulb height from each experimental plot were collected.

\subsubsection{Soil sampling and analysis}

To study and characterize the soil at the study site representative samples were taken and determination of organic matter content, $\mathrm{pH}$, texture, bulk density, moisture content at field capacity (FC) and permanent welting point (PWP) were made. Moisture content of the experimental plots before irrigation was estimated.

Prior to land preparation for the experiment, soil samples were collected from the experimental field using core sampler from the soil depths of $0-15 \mathrm{~cm}, 15-30 \mathrm{~cm}, 30-45 \mathrm{~cm}$ and $45-60 \mathrm{~cm}$ before the field was ploughed for determining physical and chemical properties of soil. Soil physical properties like textural class, bulk density, and infiltration rate, FC, PWP and TAW were determined. Soil chemical properties like $\mathrm{pH}$, Organic carbon content, Organic matter content(OM) and electrical conductivity (EC) were analyzed.

\subsubsection{Bulk density}

To determine bulk density, undisturbed soil sample of known volume were taken using core sampler from three representative places in the trial plot at four different depths $(0-15 \mathrm{~cm}, 15-30 \mathrm{~cm}, 30-45 \mathrm{~cm}$ and $45-60 \mathrm{~cm})$. The sample were dried in an oven to determine the dry weight fraction. Then bulk density was calculated as the ratio of dry weight of the soil to known cylindrical core sampler volume (Hillel, 2004).

$$
\mathrm{BD}=\mathrm{Ms} / \mathrm{Vt}
$$

where $\mathrm{BD}=$ bulk density $\left(\mathrm{g} / \mathrm{cm}^{3}\right), \mathrm{Ms}=$ dry weight of the soil $(\mathrm{g})$ and $\mathrm{Vt}=$ total volume of the soil $\left(\mathrm{cm}^{3}\right)$

\subsubsection{Field capacity and permanent wilting point}

The soil moisture content at field capacity (FC) and permanent wilting point (PWP) were determined after soil samples were saturated for one day $(24 \mathrm{hrs})$ using the pressure plate apparatus. Field capacity was determined by exerting a pressure of 0.33 bars and permanent wilting point was determined by 
exerting a pressure of 15 bars until no change in moisture was observed. The FC and permanent wilting point PWP values were further used to determine total available water(TAW)

$$
T A W=10(\theta F C-\theta P W P)
$$

where TAW $=$ total available water in the root zone $(\mathrm{mm} / \mathrm{m}), \mathrm{FC}=$ moisture content $(\mathrm{vol} . \%)$ at field capacity and PWP = moisture content (vol.\%) at permanent wilting point.

\subsubsection{Soil texture}

Soil texture was determined by hydrometer method and the soil textural class was determined using the textural triangle of USDA.

\subsubsection{Organic matter and $\mathrm{pH}$ measurements}

Titration method, which is oxidation under standardized condition with potassium dichromate in sulpheric acid, was followed for organic carbon determination. Finally, conversation of organic carbon to organic matter is therefore obtained by multiplying percentage organic carbon by 1.724 described as by Walkley and Black (1974). The degree of acidity or basicity or alkalinity is expressed by $\mathrm{pH}$. Hence, the $\mathrm{pH}$ of the soil was measured by means of $\mathrm{pH}$ meter in the supernatant suspension of $1: 2.5$, soil: liquid mixture as described by (Jackson, 1958).

\subsubsection{Soil moisture depelation and infiltration capacity}

Soil samples were also collected from each experimental plots for determining moisture depletion by using gravimetric method. The gravimetric soil moisture was determined using the expression:

$\operatorname{SMC}(\%)=\left(\mathrm{WWs}^{-\mathrm{Wds}}\right) * 100$

$$
\mathrm{Wds}
$$

where SMC is the soil moisture content at time of sampling (\%), Wws is weight of wet soil (gm) and Wds is weight of dry soil (gm).

The soil moisture depletion at any time was computed from the expression:

$\mathrm{SMD}=(\mathrm{FC}-\mathrm{SMC}) * \mathrm{BD} * \mathrm{Drz}$

where SMD is the soil moisture depleted in $\mathrm{mm}, \mathrm{FC}=$ field capacity $(\%), \mathrm{SMC}$ is the soil moisture content $(\%) \mathrm{BD}=$ bulk density $\left(\mathrm{g} / \mathrm{cm}^{3}\right)$ and Drz $=$ root depth $(\mathrm{m})$.

The volumetric water content was calculated from the gravimetric water content using the following expression.

$\theta_{\mathrm{v}}=\frac{\rho_{\mathrm{b}}}{\rho_{\mathrm{w}}} \times \theta_{\mathrm{m}}$

Where: $\theta_{\mathbf{v}}$ is volumetric moisture content in $(\%) ; \rho_{\mathrm{b}}$ is soil bulk density $\left(\mathrm{g} \mathrm{cm}^{-3}\right)$, and $\rho_{\mathbf{w}}$ is water density $\mathrm{g}$ $\mathrm{cm}^{-3}$.

The soil infiltration capacity was made using the double ring infiltrometer. Infiltration measurement was made at four random spots and the average value was made to represent the infiltration rate of the experimental site before land preparation for the experiment Infiltration characteristics of the soil was determined by ponding water in the metallic double cylinders installed in the field and observing the rate at which the water level in the cylinder was lowering. Stopwatch was used to record time and all measurements replicated three times to come on conclusion.

\subsection{Distribution Uniformity}

\subsubsection{Distribution uniformity of furrow irrigation}

To fully express the efficiency of an irrigation system, the uniformity of water applied needs to be evaluated. Distribution uniformity (DU) is a term that describes how uniformly water is applied in the field. It is the ratio of the average depth infiltrated in the low one-quarter of the field divided by the average depth infiltrated over the entire field. It is expressed as:

$$
\mathrm{DU}=\frac{\mathrm{D}_{\mathrm{lq}}}{\mathrm{D}_{\mathrm{gv}}} \times 100
$$

Where, $\mathrm{DU}=$ distribution uniformity $(\%)$,

$\mathrm{Dlq}=$ average depth of water infiltrated in the low one-quarter of the field (mm)

Dav $=$ average depth of water infiltrated over the field $(\mathrm{mm})$

\subsubsection{Distribution uniformity of drip emitters}

The uniformity of water application will be calculated in terms of coefficient of variation (CV), emitter flow variation $\left(q_{v a r}\right)$, distribution uniformity (DU), and uniformity coefficients (UC) . The coefficient of variation and emitter flow variation was calculated using equation (20) and (21) 
respectively, following the procedure recommended by $\mathrm{Wu}$ (1983).

\section{Coefficient of variation $(\mathrm{CV})$ expressed as:}

$$
\mathrm{CV}=\mathrm{S} / \mathrm{q}_{\mathrm{a}}
$$

where: $S=$ standard deviation of emitter flow rates $(1 / \mathrm{h})$ and $\mathrm{q}_{\mathrm{a}}=$ average emitter flow rate $(1 / \mathrm{h})$.

qvar $=\mathrm{qv}=(\mathrm{qmax}-\mathrm{qmin}) / \mathrm{qmax}$

Where: $\mathrm{Qmax}=$ maximum emitter flow rate $(\mathrm{l} / \mathrm{h})$ and

Qmax $=$ minimum emitter flow rate $(1 / \mathrm{h})$

The uniformity coefficients (CU) which is often described in terms of the coefficient of variation defined as the ratio of the standard deviation to the mean was calculated using equation (22) expressed as:

$\mathrm{CU}=(1-\mathrm{s} / \mathrm{qa}) \times 100$

where: $S=$ deviation of emitter flow rates $(1 / \mathrm{h})$ and

$q a=$ average emitter flow rate $(1 / \mathrm{h})$.

Distribution uniformity will be calculated using equation (23) Kruse,1978) as follows;

DU $=\left(\mathrm{q}_{1 \mathrm{q}} / \mathrm{q}_{\mathrm{a}}\right) \times 100$

where: $q a=$ average emitter flow rate $(1 / \mathrm{h})$; and

$\mathrm{q}=$ The average lowest quarter emitter flow rate $(1 / \mathrm{h})$.

\subsection{Water Use Efficiency}

The water use efficiency associated with the different irrigation treatments was calculated by dividing harvested yield in $\mathrm{kg}$ per unit of water in $\mathrm{mm}$.

\subsubsection{Crop Water Use Efficiency}

The crop water use efficiency was determined using the expression:

$\mathrm{CWUE}=\mathrm{Y} / \mathrm{ET}_{\mathrm{c}}$

Where: $C W U E=$ crop water use efficiency $\left(\mathrm{kg} \mathrm{ha}^{-1} \mathrm{~mm}^{-1}\right)$

$\mathrm{Y}=$ yield $\left(\mathrm{kgha}^{-1}\right)$ and

$\mathrm{ET}_{\mathrm{C}}=$ crop evapotranspiration $(\mathrm{mm})$

\subsubsection{Irrigation Water Use Efficiency}

The field water use efficiency was calculated from the expression:

IWUE $=\mathrm{Y} /$ Ig

Where: $I W U E=$ Irrigation water use efficiency $\left(\mathrm{kg} \mathrm{ha}^{-1} \mathrm{~mm}^{-1}\right)$

$\mathrm{Y}=$ yield $\left(\mathrm{kgha}^{-1}\right)$

$\mathrm{I}_{\mathrm{g}}=$ gross irrigation $(\mathrm{mm})$

\subsection{Data Analysis}

The effect of furrow and drip irrigation under different irrigation levels and mulching practices on the growth and yield of Onion were analyzed by using SAS statistical software and if there is a significant difference among the treatments mean separation was made using Least Significant Difference (LSD) or Duncan's Multiple Range Test (DMRT) method. To quantify the relation among irrigation levels, crop water use efficiency, Irrigation water use efficiency, and yield and yield components, correlation and regression analyses was carried out.

\section{RESULTS AND DISCUSSION}

\subsection{Soil Properties}

Some of the physical and chemical properties of the soil at the experimental site ( texture, bulk density, field capacity and permanent wilting point, organic matter content and $\mathrm{pH}$ ), were analyzed and the summarized results are presented and discussed as follows.

\subsubsection{Soil physical properties}

The results of the particle size distribution is given in Table 3. The result of the soil analysis from the experimental site showed that the composition of sand, silt and clay percentages were in the range of $36.0-28.5 \%, 45.0-35.0 \%$ and $29.0-24.0 \%$, respectively. Thus, according to the USDA soil textural classification, the percent particle size distribution for experimental site was classified as loam. 
Table 3. Summarized soil particle size distribution

\begin{tabular}{lrrrl}
\hline Depth $(\mathrm{cm})$ & \multicolumn{1}{c}{ Sand } & Silt & Clay & Textural classes \\
\hline $0-15$ & 28.5 & 45.0 & 26.5 & Loam \\
$15-30$ & 33.5 & 42.5 & 24.0 & Loam \\
$30-45$ & 36.0 & 35.0 & 29.0 & Clay loam \\
$45-60$ & 36.0 & 37.5 & 26.5 & Loam \\
Mean & 33.5 & 39.8 & 26.5 & Loam \\
\hline
\end{tabular}

\subsubsection{Bulk density, field capacity and permanent wilting point}

The bulk density of the soil of the experimental site showed a variation with depth (Table 4). It varied between 1.057 and $1.247\left(\mathrm{gm} / \mathrm{cm}^{3}\right)$. The top soil surface has slightly lower bulk density than the subsurface and this may be due to compaction of soil in greater depth of soil layer. In general, the weighted average bulk density of the soil was found to be $1.162\left(\mathrm{gm} / \mathrm{cm}^{3}\right)$.

The observed average soil moisture content at FC was varied within a narrow range of $33.8-39.3 \%$ on volume basis. The top 0-15 cm light soil surface was having lower field capacity (FC) while 15-30, 3045 , and 45-60 cm soil layers were having larger FC values on volume basis. The observed soil moisture content at PWP was also showed a variation with depth in a narrow range of $20.8-23.5 \%$ on volume basis.

The total available water (TAW) that is the amount of water that a crop can extract from its root zone was directly related to variation in FC and PWP. As a result, high value of TAW was found in the soil depth of 30$45 \mathrm{~cm}$; whereas the lower values were observed at $0-15 \mathrm{~cm}$ soil depth.

Table 4.Soil moisture constants and bulk density of experimental site

\begin{tabular}{lcccc}
\hline & & $\mathrm{FC} \%$ & $\mathrm{PWP} \%$ & \multicolumn{1}{c}{$\mathrm{PWP} \%$} \\
\cline { 2 - 5 } Sampling depth $(\mathrm{cm})$ & Bulk density $(\mathrm{gm} / \mathrm{cm} 3$ & & $\mathrm{w} / \mathrm{w}$ & \multicolumn{1}{c}{$\mathrm{mm} / \mathrm{m}$} \\
\hline $0-15$ & 1.06 & 33.80 & 18.80 & 170.10 \\
$15-30$ & 1.15 & 36.50 & 21.10 & 170.70 \\
$30-45$ & 1.19 & 39.30 & 23.50 & 180.80 \\
$45-60$ & 1.24 & 37.70 & 22.90 & 180.40 \\
Mean & 1.17 & 36.82 & 36.82 & 175.40 \\
\hline
\end{tabular}

\subsection{Soil chemical properties}

As indicated in Table 5. the $\mathrm{pH}$ of the experimental area varies from 6.74 for the depth $0-15 \mathrm{~cm}$ to 7.2 for the depth $45-60 \mathrm{~cm}$ indicating that soil is slightly alkaline and hence, suitable for crops. The soil has an electrical conductivity of 0.2 to $0.30 \mathrm{dS} / \mathrm{m}$ through the $60 \mathrm{~cm}$ soil profile. The saturated extract electrical conductivity of the soil was varied from 0.30 to $0.2 \mathrm{dS} / \mathrm{m}$ for soil depths considered (Table 5). This indicates that the soil is none saline and suitable for crop production (FAO 1985). The organic matter content of the soil varied from as low as $3.4 \%$ to as high as $7.4 \%$. The average organic matter content of the soil was about $7.0 \%$. The OM content of this experimental field had highest $7.4 \%$ in the surface soil $(0-15 \mathrm{~cm}$ depth) where as lowest $3.4 \%$ $\mathrm{OM}$ found in the bottom $45-60 \mathrm{~cm}$ soil depth. The average value of organic matter content was found to be $7.0 \%$ indicating that all the values of $\mathrm{OM}$ were with range of $3.36-7.40 \%$ and could be rated as moderate, that the field had an average structural condition with average structural stability.

Table 5. Selected soil chemical properties of the surface of the experimental field.

\begin{tabular}{lllll}
\hline & & \multicolumn{3}{l}{ soil depth $(\mathrm{cm})$} \\
\cline { 3 - 5 } soil chemical properties & $0-15$ & $15-30$ & $30-45$ & $45-60$ \\
\hline PH & 6.74 & 7.07 & 7.08 & 7.18 \\
Organic Matter content (\%) & 7.4 & 6.72 & 5.24 & 3.36 \\
Available Nitrogen (\%) & 0.37 & 0.34 & 0.26 & 0.17 \\
Organic carbon content (\%) & 4.29 & 3.90 & 3.04 & 1.95 \\
Electrical conductivty (ds/m) & 0.21 & 0.23 & 0.30 & 0.31 \\
\hline
\end{tabular}

\subsection{Distribution Uniformity of Furrow irrigation}

Distribution uniformity calculated for furrow irrigation were $87 \%, 82.6 \%$ and $78.8 \%$ at $100 \% \mathrm{MAD}, 75 \% \mathrm{MAD}$ and $125 \%$ MAD irrigation levels respectively. This result seems closely related to that of Ismail et al. (2004) who observed that distribution uniformity of surface irrigation greater than $80 \%$ are homogenous, greater than $70 \%$ slightly homogenous and less than 70\% non homogenous. FAO (1992) also suggested that the average distribution efficiency DU of $65 \%$ as sufficient and DU of $30 \%$ as poor.

\subsection{Distribution Uniformity of Drip Emitters}

The measured values of emitter discharge uniformity parameters were presented in table 6 . Analysis of data on emitter discharge observation under all parameters has shown better performance.The values of distribution 
uniformities $(\mathrm{Du})$ and uniformity coefficient $(\mathrm{Cu})$ were $96.23 \%$ and $97.84 \%$, respectively. The field distribution uniformity was excellent, emitter coefficient of variation was good and according to Bralts (1986) emitter flow variation was acceptable.

Table 6. Uniformity of drip irrigation

\begin{tabular}{lcc}
\hline \multicolumn{1}{c}{ Parameters } & Units & Average \\
\hline Distribution uniformities (Du) & $\%$ & 96.23 \\
Emitter flow variation (qv ) & $\%$ & 6.77 \\
Coefficient of variation (Cv) & $\%$ & 2.10 \\
Uniformity coefficient $(\mathrm{Cu})$ & $\%$ & 97.84 \\
\hline
\end{tabular}

\subsection{Irrigation Water Application in the Experimental Area.}

Seasonal crop water requirement of onion determined based on the seasonal water application depth from transplanting to harvest and vary based on the irrigation level of treatments. Common irrigation depth of 26.5 $\mathrm{mm}$ was applied for all treatments from transplanting for well establishment of the onion before treatment start. During the experiment there were rainfall and the total rainfall recorded was $21.5 \mathrm{~mm}$ then effective precipitation was calculated. The total result of calculated effective rainfall was $12.25 \mathrm{~mm}$ that reduced from net irrigation depth during the next irrigation treatment application (Table 7).

The total gross depths of irrigation water applied in $\mathrm{mm}$ through both irrigation methods were varied (Table 7). The variation of application depth occurred between these irrigation methods were due to high and low application efficiency of drip (90\%) and furrow irrigation (60\%), respectively. Only a fraction of the soil surface between 15 to 60 percent is wetted in drip irrigation system (Segal et al., 2000). The total net and gross depths of irrigation water applied in $\mathrm{mm}$ for mulch and no mulch treatments were varied (Table 7). The variation of application depth occurred between these treatments were due to the effectiveness of plastic mulches to conserve moisture.

Table 7.Seasonal Crop and irrigation water requirement of onion crop

\begin{tabular}{ccccccc}
\hline Treatments & $\begin{array}{c}\text { IRn } \\
(\mathrm{mm})\end{array}$ & $\mathrm{P}_{\text {ef }}(\mathrm{mm})$ & $\begin{array}{c}\text { CWR } \\
(\mathrm{mm})\end{array}$ & $\begin{array}{c}\text { IRg } \\
(\mathrm{mm})\end{array}$ & $\begin{array}{c}\text { CWUE } \\
(\mathrm{kg} / \mathrm{ha} . \mathrm{mm})\end{array}$ & $\begin{array}{l}\text { IWUE } \\
(\mathrm{kg} / \mathrm{ha} . \mathrm{mm})\end{array}$ \\
\hline T1 & 476.4 & 12.25 & 488.65 & 529.3 & 0.86 & 0.77 \\
T2 & 595.5 & 12.25 & 607.75 & 661.7 & 0.62 & 0.56 \\
T3 & 465.3 & 12.25 & 477.55 & 517.0 & 0.80 & 0.72 \\
T4 & 581.6 & 12.25 & 593.85 & 646.3 & 0.58 & 0.53 \\
T5 & 455.6 & 12.25 & 467.85 & 506.2 & 0.75 & 0.67 \\
T6 & 569.5 & 12.25 & 581.75 & 661.7 & 0.56 & 0.48 \\
T7 & 476.4 & 12.25 & 488.65 & 794.0 & 0.64 & 0.39 \\
T8 & 595.5 & 12.25 & 607.75 & 992.2 & 0.50 & 0.30 \\
T9 & 465.3 & 12.25 & 477.55 & 777.5 & 0.64 & 0.39 \\
T10 & 581.6 & 12.25 & 593.85 & 969.4 & 0.49 & 0.30 \\
T11 & 455.5 & 12.25 & 467.75 & 759.3 & 0.59 & 0.35 \\
T12 & 569.5 & 12.25 & 581.75 & 949.1 & 0.46 & 0.27 \\
\hline
\end{tabular}

$\mathrm{IRn}=$ net irrigation requirement, $\mathrm{IRg}=$ gross irrigation requirement, $\mathrm{CWR}=$ crop water requirement ,CWUE Crop water use efficiency,IWUE Irrigation water use efficiency and $\mathrm{P}_{\mathrm{ef}}=$ effective rainfall .

\subsection{Effects of Irrigation Methods and MAD Levels on Crop Physiology}

The response of onion physiology like number of leaves per plant, plant height and leaf height to irrigation methods and MAD level with and whith out mulch is presented in table 8. 
Table 8 .Effect of irrigation methods and water application under mulching on crop physiology

\begin{tabular}{|c|c|c|c|}
\hline Plant height $(\mathrm{cm})$ & Leave height $(\mathrm{cm})$ & Leave number & \\
\hline DI & $67.4 \mathrm{a}$ & $54.9^{\mathrm{a}}$ & $13.2^{\mathrm{a}}$ \\
\hline FI & $58.6^{\mathrm{b}}$ & $47.7^{b}$ & $11.6^{\mathrm{b}}$ \\
\hline $\operatorname{LSD}(0.05)$ & 1.3 & 1.1 & 0.9 \\
\hline CV $(\%)$ & 4.3 & 4.3 & 4.3 \\
\hline $75 \%$ MADPM & $66.0^{\mathrm{a}}$ & $53.8^{\mathrm{a}}$ & $13.0^{\mathrm{a}}$ \\
\hline 75\% MADNM & $64.8^{\mathrm{ab}}$ & $52.8^{\mathrm{ab}}$ & $12.8^{a b}$ \\
\hline $100 \%$ MADPM & $64.7^{\mathrm{ab}}$ & $52.7^{\mathrm{ab}}$ & $12.5^{a b c}$ \\
\hline $100 \%$ MADNM & $62.2^{\mathrm{abc}}$ & $50.7^{\mathrm{abc}}$ & $12.3^{\mathrm{bc}}$ \\
\hline $125 \%$ MADPM & $61.2^{\mathrm{bc}}$ & $49.8^{\mathrm{bc}}$ & $12^{\mathrm{c}}$ \\
\hline $125 \%$ MADNM & $58.9^{\mathrm{c}}$ & $48.0^{\mathrm{c}}$ & $12^{\mathrm{c}}$ \\
\hline LSD (0.05) & 3.9 & 3.3 & 0.6 \\
\hline $\mathrm{Cv}(\%)$ & 6.1 & 4.1 & 3.1 \\
\hline
\end{tabular}

\subsubsection{Number of green leaves per plant}

The analysis of variance (Table 11) for green leaves per plant revealed that there was significant effect at $(\mathrm{p}<$ 0.05 ) due to irrigation methods. The mean values of leaves per plant were 11.6 and $13.2 \mathrm{~cm}$ for irrigation methods of furrow and drip irrigation respectively (Table 8). The mean value of drip irrigation method was higher than that of furrow irrigation method and the means were highly significantly $(\mathrm{p}<0.05)$ difference.

The effects of MAD level under mulching on green leaves per plant were significant at $(\mathrm{p}<0.05)$. Table 8 , shows that, as the application of irrigation level increased from 75\%MAD under plastic mulch and no mulch to $125 \%$ MAD under plastic mulch and no mulch, a significant decreasing green leaves per plant was observed. The maximum green leaves per plant was recorded from treatment received 75\%MAD with plastic mulch (13.0) followed by $75 \%$ MAD under nomulch (12.8). Based on the results, the drip irrigation method resulted in increased leaf number by $12.8 \%$ as compared to furrow irrigation method. Channagoudar and Janawade (2010) and Bagali et al. (2012) reported that scheduling of drip irrigation significantly increased the growth parameters.

\subsubsection{Plant height}

The analysis of variance (Table 8)has indicated that there was significant $(\mathrm{p}<0.05)$ effect on plant height due to irrigation application methods. The mean value of plant height recorded from drip irrigation method was higher and significantly $(\mathrm{p}<0.05)$ different from furrow irrigation. These findings agree with those of Bhonde et al. (2003); Bhasker et al. (2018) who reported that maximum plant height was recorded under drip irrigation method.

As shown in table 8,the highest plant height $(66.0 \mathrm{~cm})$ was obtained from $75 \% \mathrm{MAD}$ level under pilastic mulch and was not significantly different from $100 \%$ MAD level under pilastic mulch, while the shortest mean plant height $(58.9 \mathrm{~cm})$ was observed on the application of $125 \%$ MAD level under no mulch and statistically different with $100 \%$ MAD level with and without mulch. The result obtained agrees with observations in other irrigation studies on onion by different researchers. The increasing of plant height with adequate soil moisture application is related to water in maintaining the turgid pressure of the plant cells which is the main reason for the plant growth (Doorenbos and Pruitt, 1992). This study outcome is in line with the research that was done by El-Noemani et al. (2009), indicated that soil water supply is directly proportional with plant height growth. The findings of many researchers suggest that the fairly shorter interval of irrigation replenishes soil moisture on 1520 percent depletion, depending upon the type of soil, climate and season of cultivation. The reason for the better performance of this growth parameter due to the shorter interval of irrigation may be attributed to optimum soilwater-air balance around plant root zone. These results were in line with the results of Kadam et al. (2006).

\subsubsection{Leaf height}

Analysis of variance in Appendix table 13 indicated that irrigation application methods and MAD level had asignificant $(\mathrm{P}<0.05)$ effect on onion leaf height. The taller mean leaf height $(54.9 \mathrm{~cm})$ was recorded from drip irrigation method which was significantly different from that of furrow irrigation (Table 8). The tallest mean leaf height of $53.8 \mathrm{~cm}$ was observed for $75 \%$ MAD level with mulch which was not significantly different from the $100 \%$ MAD irrigation level. The least mean leaf height $(48.0 \mathrm{~cm})$ was recorded from $125 \%$ MAD level whithout mulch and had significant difference from $100 \%$ MAD irrigation level. Generally, increasing trend in leaf height was observed with a decreasing MAD level indicating direct relationship between vegetative growth and irrigation frequency. This might be because plants did not suffer from water deficit in short irrigation intervals. Reducing the time interval between successive irrigations in order to maintain constant, optimal water content in the root zone may reduce the variations in nutrient concentration, thereby increasing their availability to plants (Silber et al., 2003). According to Radin et al. (1989), frequent irrigations prevent the large fluctuation in plant water stress caused by infrequent irrigations. 
3.7. Effects of Irrigation Methods and MAD Levels on Crop Yield and yield components

Table 9. Effects of irrigation method and MAD levels under mulching on crop yield and yield components

\begin{tabular}{|c|c|c|c|c|}
\hline Treatment & $\begin{array}{l}\text { Marketable } \\
\text { bulb yield(ton) }\end{array}$ & Total Bulb yield(ton) & $\begin{array}{l}\text { Bulb } \\
\text { diameter }(\mathrm{cm})\end{array}$ & Bulb height $(\mathrm{cm})$ \\
\hline DI & $32.9^{\mathrm{a}}$ & $36.9^{\mathrm{a}}$ & $5.6^{\mathrm{a}}$ & $5.8^{\mathrm{a}}$ \\
\hline FI & $25.8^{b}$ & $30.1^{\mathrm{b}}$ & $4.9^{b}$ & $4.9^{b}$ \\
\hline LSD (0.05) & 9.3 & 4.3 & 0.4 & 0.9 \\
\hline $\mathrm{CV}(\%)$ & 4.3 & 8.6 & 4.3 & 4.3 \\
\hline $\operatorname{SEm}( \pm)$ & 1.5 & 1.4 & 0.1 & 0.1 \\
\hline $75 \%$ MADPM & $33.1^{\mathrm{a}}$ & $37.1^{\mathrm{a}}$ & $5.6^{\mathrm{a}}$ & $5.8^{\mathrm{a}}$ \\
\hline 75\% MADNM & $29.7^{b}$ & $34.6^{b}$ & $5.3^{\mathrm{c}}$ & $5.6^{\mathrm{ab}}$ \\
\hline $100 \%$ MADPM & $29.9^{b}$ & $35.2^{b}$ & $5.4^{\mathrm{b}}$ & $5.5^{\mathrm{ab}}$ \\
\hline $100 \%$ MADNM & $28.3^{b c}$ & $32.9^{c}$ & $5.2^{\mathrm{c}}$ & $5.3^{b c}$ \\
\hline $125 \%$ MADPM & $28.6^{\mathrm{bc}}$ & $30.7^{\mathrm{d}}$ & $5.1^{\mathrm{c}}$ & $5.1^{\mathrm{cd}}$ \\
\hline $125 \%$ MADNM & $26.7^{\mathrm{c}}$ & $30.5^{\mathrm{d}}$ & $5.0^{\mathrm{d}}$ & $4.8^{\mathrm{d}}$ \\
\hline $\operatorname{LSD}(0.05)$ & 25.7 & 10.5 & 0.1 & 0.3 \\
\hline $\mathrm{Cv}(\%)$ & 8.08 & 4.1 & 2.1 & 5.1 \\
\hline
\end{tabular}

\subsubsection{Total bulb yield}

The yield of onion crop was significantly $(\mathrm{p}<0.05)$ affected by irrigation methods .Table 9, indicates that the furrow irrigation method was resulted in low total yield of (30.1 ton/ha) as compared to that obtained under drip irrigation (36.9 ton/ha) method. This might be due to water stress during the critical growth period, coupled with aeration problem in first few days immediately after irrigation. Another reason to get low yield by furrow irrigation might be due to less availability of nutrients for crop growth due to leaching with high weed infestation between the crops Pattanaiket al.(2003). This result is supported by the findings of Tiwari et al. (1998a)and Tiwari et al. (1998b). In drip irrigation system, water is applied at a low rate for a longer period at frequent intervals near the plant root zone through lower pressure delivery system, which increases the availability of nutrients near the root zone with a reduction in leaching losses. Based on the results, drip irrigation method was resulted inincreased yield by $22.4 \%$ as compared to furrow irrigation method.There was also significant difference observed between mean at $(\mathrm{p}<0.05)$. These results are in agreement with those Yohannes and Tadesse (1998) reported that a higher yield of tomato was obtained with drip irrigation as compared to furrow irrigation. Raina et al.,(1998) reported that drip irrigation gave 49.5\% higher yield than the surface irrigation of pea crop. In addition, total yield of the crop was also highly significantly affected $(p<0.05)$ due to different level of water application under mulching. Table 9 revealed that, the application of 75\% MAD under plastic mulch and $125 \%$ MAD under plastic mulch showed a significant decreasing total yield of the crop as compared to $100 \%$ MAD under plastic mulch respectively. The maximum total yield was obtained from treatment received $75 \%$ MAD under plastic mulch (37.1 ton/ha) followed by $100 \%$ MAD underplastic mulch (35.2 ton/ha) while, the lowest mean total yield was observed on the application of $125 \% \mathrm{MAD}$ under no mulch (30.5ton/ha).

\subsection{2 .Marketable bulb yield}

As indicated in table 10 ,furrow irrigation method has resulted in a low marketable bulb yield of (25.8 ton/ha) as compared to that obtained under drip irrigation method (32.8 ton/ha). Based on the results, the drip irrigation method was resulted in increased marketable bulb yield by $21.2 \%$ as compared to furrow irrigation method.The low marketable bulb yield from furrow irrigation might be due to less availability of nutrients for crop growth due to leaching (Pattanaik et al.,2003). In drip irrigation system, water is applied at a low rate for a longer period at frequent intervals near the plant root zone through lower pressure delivery system, which increases the availability of nutrients near the root zone with a reduction in leaching losses. Drip irrigation ensures optimum growth, better bulbing and early maturity of crops by assuring optimum soil moisture, water, air and nutrients throughout the crop growing period resulting uniform bulb obtained and correlated to the highest bulb size and productivity, whereas in surface irrigation yield decreased due to deep percolation and water is lost beyond the active absorption zone of the root system as an onion is shallow rooted crop.

The highest marketable bulb yield (33.1 ton/ha) was obtained under 75\% MAD level under mulch and the smallest marketable bulb yield (26.7 ton/ha) was observed under 125\% MAD level under no mulch.

This reveals that there was a decreasing trend in bulb yield for an increase in MAD level,indicating that increasing the irrigation application interval resulted in a corresponding decreasing of mean yield values. Increased bulb yield of onion by ashorter interval of irrigation may be due to the better performance of growth parameters like plant height and number of leaves.

As shown in table 9, the highest marketable bulb yield of 33.1 ton/ha was obtained from drip irrigation at $75 \%$ MAD with plastic mulch application and significantly different to all other treatments. The lowest yield of 26.7 ton/ha was obtained from furrow irrigation at 125\% MAD without plastic mulch application and had 
significantly different to all other treatments. The current result was in confirmation with study result of Bagali et al. (2012) who reported that scheduling of drip irrigation at shorter intervals significantly increased the growth parameters and significantly higher bulb yield as compared to flood irrigation.

In addition, marketable yield of the crop was also highly significantly affected $(p<0.05)$ due to different level of water application under mulching. Table 9 revealed that, the application of $75 \%$ MAD under plastic mulch to 125 MAD under plastic mulch showed a significant decreasing marketable yield of the crop respectively. Therefor, marketable yield were decreasing within the same water application level under mulch as irrigation levels increase.

\subsubsection{Bulb diameter}

The analysis of variance indicated that MAD level had a highly significant $(\mathrm{P}<0.01)$ effect on bulb diameter.As indicated intable 9, the largest bulb diameter $(5.6 \mathrm{~cm})$ was obtained from the drip irrigation method which was significantly $(\mathrm{P}<0.05)$ different from that obtained from furrow irrigation method $(4.9 \mathrm{~cm})$.

The largest bulb size $(5.6 \mathrm{~cm})$ was obtained from $75 \%$ MAD with mulch and was significantly different to all other treatments, while the smallest bulb diameter $(5.0 \mathrm{~cm}$ ) was obtained from $125 \%$ MAD. This reveals that there was a decreasing trend in bulb size for an increase in MAD level, indicating that increasing the irrigation application interval was resulted in a corresponding decreasing of mean bulb size. The shorter irrigation interval ensures the optimum growth of the crop by assuring balanced water and nutrient supply throughout the crop growth period. Al-Moshileh (2007), reported that bulb diameter increased with increasing soil moisture level.The study by Ayas and Demirtaș (2009) indicates that bulb diameter has an increasing trend with the level of irrigation application.

As depicted in table 9, the highest bulb diameter of $5.6 \mathrm{~cm}$ was obtained from drip irrigation at $75 \%$ MAD with mulch application and significantly different from all other treatments. The lowest bulb diameter of $5.0 \mathrm{~cm}$ was obtained from furrow irrigation at 125\% MAD without mulch application and significantly different from all other treatments.

\subsubsection{Bulb height}

The analysis of variance indicated that MAD level had a highly significant $(\mathrm{P}<0.05)$ effect on bulb height. As indicated intable 10, the largest bulb height $(5.8 \mathrm{~cm})$ was obtained from the drip irrigation method which was significantly $(\mathrm{P}<0.05)$ different from that obtained from furrow irrigation method $(4.9 \mathrm{~cm})$.

The largest bulb height $(5.8 \mathrm{~cm})$ was obtained from 75\% MAD with mulch and was significantly different to all other treatments, while the smallest bulb height $(4.8 \mathrm{~cm})$ was obtained from $125 \%$ MAD without mulch. This reveals that there was a decreasing trend in bulb height for an increase in MAD level, indicating that increasing the irrigation application interval was resulted in a corresponding decreasing of mean bulb size. The shorter irrigation interval ensures the optimum growth of the crop by assuring balanced water and nutrient supply throughout the crop growth period. Al-Moshileh (2007), reported that bulb height increased with increasing soil moisture level.

\subsection{Crop Water Use Efficiency (CWUE)}

The The analysis of variance indicated that MAD level had a highly significant $(\mathrm{P}<0.05)$ effect on bulb height due to irrigation methods. The mean values of crop water use efficiency were observed as 0.58 and $0.72 \mathrm{~kg} / \mathrm{m}^{3}$ for irrigation methods of furrow and drip irrigation methods respectively (Table 10). The mean value of drip irrigation method was higher than that of furrow method and the means were significantly different at $(p<0.05)$ (Table 10). The results resembled the findings of Begum et al., (2001).

Table 10 revealed that, crop water use efficiency was decreased as the application of irrigation level increased from $75 \%$ MAD under the mulching order of plastic mulch and no mulch to $125 \%$ MAD the mulching order of plastic mulch and no mulch respectively. The maximum crop water use efficiency was recorded from treatment received $75 \%$ MAD under plastic mulch $\left(0.88 \mathrm{~kg} / \mathrm{m}^{3}\right)$ followed by $100 \%$ MAD under plastic mulch $\left(0.80 \mathrm{~kg} / \mathrm{m}^{3}\right)$ while, the lowest mean irrigation water use efficiency was observed on the application of $125 \%$ MAD under no mulch $\left(0.48 \mathrm{~kg} / \mathrm{m}^{3}\right)$. The result of this study indicated that, increasing in the irrigation water application level in the order of plastic mulching and no mulching respectively resulted a corresponding decreasing of mean crop water use efficiency values.

\subsection{Irrigation Water Use Efficiency (IWUE)}

The mean values of irrigation water use efficiency were observed as 0.35 and $0.64 \mathrm{~kg} / \mathrm{m}^{3}$ for irrigation methods of furrow and drip irrigation methods respectively (Table 10). The mean value of drip irrigation method was higher than that of furrow method and the means were significantly different at $(p<0.05)$ (Table 10). The results resembled the findings of Begum et al., (2001).

Table 10 revealed that, irrigation water use efficiency was decreased as the application of irrigation level increased from $75 \% \mathrm{MAD}$ under the mulching order of plastic mulch and no mulch to $125 \%$ MAD the mulching order of plastic mulch and no mulch respectively. The maximum irrigation water use efficiency was 
recorded from treatment received $75 \%$ MAD under plastic mulch $\left(0.80 \mathrm{~kg} / \mathrm{m}^{3}\right)$ followed by $100 \%$ MAD under plastic mulch $\left(0.75 \mathrm{~kg} / \mathrm{m}^{3}\right)$ while, the lowest mean irrigation water use efficiency was observed on the application of $125 \%$ MAD under no mulch $\left(0.29 \mathrm{~kg} / \mathrm{m}^{3}\right)$. The result of this study indicated that, increasing in the irrigation water application level in the order of plastic mulching and no mulching respectively resulted a corresponding decreasing of mean irrigation water use efficiency values.

Table 10. Effects of irrigation methods and MAD levels on crop and irrigation water use efficiency

\begin{tabular}{|c|c|c|}
\hline Treatment & CWUE & IWUE \\
\hline DI & $0.72^{\mathrm{a}}$ & $0.64^{\mathrm{a}}$ \\
\hline FI & $0.58^{b}$ & $0.35^{b}$ \\
\hline $\operatorname{LSD}(0.05)$ & 2.327 & 4.3 \\
\hline CV (\%) & 1.12 & 0.34 \\
\hline $\operatorname{SEm}( \pm)$ & 0.306 & 2 \\
\hline $\mathrm{T} 1$ & $0.88^{a}$ & $0.80^{\mathrm{a}}$ \\
\hline $\mathrm{T} 2$ & $0.63^{\mathrm{e}}$ & $0.57^{\mathrm{d}}$ \\
\hline $\mathrm{T} 3$ & $0.84^{\mathrm{b}}$ & $0.75^{\mathrm{b}}$ \\
\hline $\mathrm{T} 4$ & $0.61^{\text {ef }}$ & $0.55^{\mathrm{d}}$ \\
\hline T5 & $0.73^{c}$ & $0.66^{c}$ \\
\hline T6 & $0.59^{f}$ & $0.51^{\mathrm{e}}$ \\
\hline $\mathrm{T} 7$ & $0.67^{\mathrm{d}}$ & $0.41^{\mathrm{f}}$ \\
\hline T8 & $0.53^{g}$ & $0.32^{\mathrm{h}}$ \\
\hline T9 & $0.67^{\mathrm{d}}$ & $0.40^{f}$ \\
\hline $\mathrm{T} 10$ & $0.53^{\mathrm{g}}$ & $0.32^{h}$ \\
\hline $\mathrm{T} 11$ & 0.61 ef & $0.36^{\mathrm{g}}$ \\
\hline $\mathrm{T} 12$ & $0.48^{\mathrm{f}}$ & $0.29^{\mathrm{i}}$ \\
\hline LSD (0.05) & 2.572 & 2.08 \\
\hline $\mathrm{Cv}(\%)$ & 2.55 & 2.51 \\
\hline
\end{tabular}

\section{Conclusions and Recommendation}

\subsection{Conclusions}

Irrigation treatments had significant effect on yield and yield components considered in the study. Irrigation methods and MAD levels had a significant $(\mathrm{p}<0.05)$ effect on onion vegetative parameters like number of leaves per plant, plant height and leaf height and yield parameters like bulb diameter, bulb height, total bulb yield, marketablebulb yield, crop water use efficieny and irrigation water use efficieny productivity. Drip irrigation was working efficiently according to its design. Drip irrigation method saved 33.3\% water and increased yield by $21.6 \%$ as compared to furrow irrigation method. Higher Crop water use efficiency and Irrigation water use efficiency of about $0.72 \mathrm{~kg} / \mathrm{m}^{3}$ and $0.64 \mathrm{~kg} / \mathrm{m}^{3}$ were obtained in drip irrigation method respectively; whereas lower Crop water use efficiency and Irrigation water use efficiency of about $0.58 \mathrm{~kg} / \mathrm{m}^{3}$ and $0.35 \mathrm{~kg} / \mathrm{m}^{3}$ were obtained in furrow irrigation method. Irrigation treatments had significant effect on yield and yield components considered in the study. Generally among all tested treatments drip irrigation method with 75\% MAD under plastic mulch was the best practice because of its high total yield and better moisture conservation ability.

\subsection{Recommendation}

From the observation made during this research, the following points were further recommended:

- When there is scarcity of water near small holders farm, farmers can use drip irrigation at the light and frequent $(75 \% \mathrm{MAD}$ level) with plastic mulch to achieve high yield and water use efficiency. However, if there is excess amount of water one can use furrow irrigation with plastic mulch.

- Gravimetric method was used to monitor soil moisture content, but it is also advisable to use other device with more accuracy like neutron prop ,TDR and Tensio meter.

- The experiment was a one season and in one place. Hence, repeating the experiment will improve the validity of findings.

- $\quad$ The test crop here was onion but, comparison should be extended to other commercial crops.

- Growers will need to exercise when and how much to apply in managing the rate, frequency, and duration of water supplies to successfully allocate limited water resource.

\section{References}

Ali M and Talukder M (2008). Increasing water productivity in crop production - A synthesis. Agri. Water Manag., 95: 201-1213. https://doi.org/10.1016/j.agwat.2008.06.008. 
Allen, R.G. L.S. Pereira, D. Raes and M.Smith, 1998. Crop evapotranspiration. Guidelines for computing crop water requirements.FAO Irrig.Drain. Paper No. 56. FAO, Rome, Italy.

Ayas, S. and Demirtaş, Ç. 2009. Deficit irrigation effects on onion (Allium cepa LET Grano 502) yield in unheated greenhouse condition. J Food, Agri. and Envi., 7(3/4): 239-243.

Begum MN, Karim AJMS, Rahman MA, Egashira K. 2001. Effect of irrigation and application of phosphorus fertilizer on the yield and water use of tomato grown on a clay terrace soil of Bangladesh.J Faculty Agric, Kyushu University. 45(2):611-619.

Bralts, V.F. 1986. Field Performance and evaluation: In trickle irrigation for crop production. Design, operation and management (Nakayama FS and Bucks SA, Eds.) Amsterdam, 216-240.

Brewster, J. L. 1990. Physiology of crop growth and bulbing. In: H.D. Rabinowitch and J. L. Brewster (eds.). Onions and allied crops. Botany, physiology and genetics. CRC Press, Boca Raton, Florida. pp54-80

Channagoudar, R.F. and Janawade, A.D. 2010. Effects of different levels of irrigation and sulphur on growth, yield and quality of onion (Allium cepa L.). Karnataka J. Agric. Sci., 19(3): 489-492.

Doorenbos, J. and Kassam A.H.1979. Yield Response to Water. FAO Irrigation and Drainage Paper Number, 33 , Rome.

Doorenbos, J. and Pruitt, W.O. 1992. Crop water requirements. FAO irrigation and drainage paper 24, FAO, Rome Italy.

Evans, R. G., and E. J. Sadler. 2008. Methods and technologies to improve efficiency of water use. Water Resource Research 44: W00E04.

El-Noemani, A.A. Aboamera, M.A. Aboellil, A.A. and Dewedar, O.M. 2009. Growth, yield, quality and water use efficiency of pea (Pisum sativum L.) plants as affected by evapotranspiration (ETo) and sprinkler height. J.Agric.Res., 34(4): 1445-1466.

FAO, 1977. Guidelines for Designing and Evaluating Surface Irrigation Systems. Irrigation and Drainage Paper No.45, Rome, Italy.

FAO (Food and Agricultural Organization), 1992. Ninth Meeting of east and southern African Subcommittee for Soil Correlation and Land evaluation. Soil Bulletin No.70. FAO, Rome, Italy.

Gardenas, A. Hopmans, J.W., Hanson, B.R., Šimůnek, J. 2005. Two dimensional modeling of nitrate leaching for various fertigation scenarios under micro-irrigation. Agric. Water Manage, 74: 219-242.

Hillel, D. 2004. Introduction to environmental soil physics. University of Massachusetts, ELESIVIER Academic Press. New York. 493p.

Jackson, M.L. 1958. Soil chemical analysis. Prentice-Hall Inc., Englewood Cliffs, New Jersey pp. 582.

Kadam, U.S. Gorantiwar, S.D., Kadam, S.A., Gurav, G.B. and Patil, H.M. 2006. Effects of different soil moisture regimes on yield potential of onion (Allium cepa L.) under micro sprinkler irrigation system. $J$. Maharashtra Agric. Univ., 31(3): 342-345.

Kijne J, Barker R, Molden D (2003). Water Productivity in Agriculture: Limits and Opportunities for Improvement. IWMI,

Kruse, E.G. 1978.Describing irrigation efficiency and uniformity. J. Irrig. and Drain Div.,

ASCE 104 (IR1), pp. 35-41.

Mekonnen, M. M. and A. Y. Hoekstra, 2016. Four billion people facing severe water scarcity. Science Advances, 2, e1500323.1: 352.

Naglič, B. 2014. Numerical and experimental evaluation of wetted soil volume in surface drip irrigation systems. Doct. dissertation. University of Ljubljana, Ljubljana, Slovenia.

Palanisami K (2002). Economics of irrigation technology transfer and adoption. Tamil Nadu Agricultural University. Coimbatore, India. www.fao.org/docrep/W7314E/w7314eof, accessed on June 2017.

Pattanaik, S .K. Sahu, N. Pradhan, P. C. and Mohanty, M. K. 2003. Response of Banana todrip irrigation under different irrigation designs. Journal of Agricultural Engineering, ISAE, 40(3):29-34.

Paul J C, Mishra J N, Pradha PL and Panigrahi B.2013. Effect of Drip and Surface Irrigation on Yield, Water Use Efficiency And Economics Of Capsicum (CapsicumAnnuml.)Grown Under Mulch and Non Mulch Conditions in Eastern Coastal India. European Journal of Sustainable Development (2013), 2, 1, 99-108

Playán E, Mateos L (2006). Modernization and optimization of irrigation systems to increase water productivity. Agric. Water Manage, 80 (1-3), 100-116. http://dx.doi:10.1016/j.agwat.2005.07.007.

Radin, J.W. Mauney, J.R. and Kerridge, P.C. 1989. Water uptake by cotton roots during fruit filling in relation to irrigation frequency. Crop sci., 29(4): 1000-1005.

Reddy R (2010). Irrigation Engineering. Gene-tech books, New Delhi.

Segal, E. Ben-Gal, A. and Shani, U. 2000. Water availability and yield response to high-frequency microirrigation in sunflowers. The $6^{\text {th }}$ International Micro-irrigation congress on 'Micro irrigation technology for developing agriculture'. Conference papers, 22-27 October, South Africa

Scholten, W., 2007. Agricultural development and water use in the Central Rift Valley of Ethiopia: A rapid appraisal. Internship Report. University of Twenty 
Silber, A. Xu, G. Levkovitch, I. Soriano, S. Bilu, A. and Wallach, R. 2003. High fertigation frequency: the effects on uptake of nutrients, water and plant growth. Plant and soil, 253(2): 467-477.

Solaimalai A, Baskar M, Sadasakthf A, Subburamu K (2005). Fertigation in high-value crops; a review. Agric. Rev., 26 (1): 1-13.

Tiwari K .N. Mal, P K, Singh R M and Chattopadhya A. 1998a. Response of Okra to dripirrigation under mulch and non-mulch conditions. Agricultural Water Management, 38: 91-102.

Tiwari K N, Singh, R M, Mal P K and Chattopadhya A. 1998b. Feasibility of drip Irrigation under different soil covers in tomato. Journal of Agricultural Engineering, ISAE, 35(2): 41-49.

Walkley, A. and Black, I.A. 1934. An examination of the Degtjareff method for determining soil organic matter, and a proposed modification of the chromic acid titration method. Soil science, 37(1), 29-38.

Wu, I.P., 1983. A unit-plot for drip irrigation lateral and sub-main design.ASAE paper, St. Joseph, MI 49085. No. 83-1595. 